\title{
IMPLEMENTASI MODEL AUTOREGRESSIVE INTEGRATED MOVING AVERAGE (ARIMA) UNTUK PERAMALAN JUMLAH PENUMPANG KERETA API DI PULAU SUMATERA
}

\author{
Isop Siti Nurjanah', Dadang Ruhiat ${ }^{2}$, Dini Andiani ${ }^{3}$ \\ 1,2,3 Program Studi Matematika FMIPA Universitas Bale Bandung \\ email : isop_janah@yahoo.com
}

\begin{abstract}
ABSTRAK
Pemodelan dan peramalan runtun waktu saat ini sering digunakan di berbagai bidang termasuk di bidang transportasi, baik transportasi darat, laut maupun transportasi udara. Akhir-akhir ini masyarakat banyak menggunakan transportasi darat dengan menggunakan jasa layanan dari PT. Kereta Api Indonesia. Terkait hal tersebut, penelitian ini membahas tentang pemodelan dan peramalan jumlah penumpang PT. Kereta Api Indonesia secara khusus untuk wilayah operasi di Pulau Sumatera dengan menggunakan pendekatan metode Box-Jenkins, yaitu model Autoregressive Integrated Moving Average (ARIMA). Pemodelan dan peramalan dalam penelitian ini menggunakan data jumlah penumpang PT. Kereta Api Indonesia di Pulau Sumatera selama 11 (sebelas) tahun terakhir yaitu dari periode Januari 2006 sampai dengan Desember 2016. Model ARIMA terbaik untuk peramalan adalah model yang memenuhi syarat signifikansi parameter, white noise dan memiliki nilai MAPE (Mean Absolute Percentage Error) yang terkecil. Hasil analisis menunjukkan model terbaik untuk peramalan jumlah penumpang PT. Kereta Api Indonesia di Pulau Sumatera adalah model ARIMA $(1,1,1)$ dengan nilai MAPE in sample sebesar $12.28 \%$ dan nilai MAPE out of sample untuk kalibrasi model sebesar $5.11 \%$. Dengan demikian model ARIMA $(1,1,1)$ cocok dan layak digunakan untuk peramalan jumlah penumpang PT. Kereta Api Indonesia di Pulau Sumatera.
\end{abstract}

Kata kunci: Box-Jenkins, ARIMA, MAPE, Kalibrasi, Peramalan.

Dikirim: 26 Juni 2018; Diterima: 17 September 2018; Dipublikasikan: 29 September 2018

Cara sitasi: Nurjanah, I.S., Ruhiat, D., dan Andiani, D. 2018. Implementasi Model Autoregressive Integrated Moving Average (ARIMA) untuk Peramalan Jumlah Penumpang Kereta Api di Pulau Sumatera. Jurnal Teorema: Teori dan Riset Matematika. Vol 3 No 2, Hal 145-156, September 2018. 
-146 Jurnal Teorema: Teori dan Riset Matematika Vol 3 No 2, Hal 146-156, September 2018

\section{PENDAHULUAN}

Peramalan pada dasarnya merupakan suatu dugaan atau perkiraan atas kejadian di waktu mendatang. Peramalan merupakan alat bantu yang penting dalam perencanaan yang efektif dan efisien (Makridakis, dkk., 1999: 3). Peramalan sering digunakan pada bidang ekonomi, perencanaan produksi, peramalan penjualan, dan kontrol stok. Meramal juga dapat didasarkan pada keahlian penilaian, yang ada pada gilirannya didasarkan pada data historis dan pengalaman (Makridakis, dkk., 1999: 519). Tingkat keakuratan hasil peramalan dalam pemilihan metode peramalan harus dilakukan dengan teliti agar bisa dipertanggungjawabkan. Salah satu metode peramalan yang sering digunakan adalah runtun waktu (time series).

Runtun waktu (time series) adalah analisis yang mempertimbangkan pengaruh waktu secara beruntun. Data-data yang dikumpulkan berdasarkan urutan waktu seperti, jam, hari, minggu, bulan, kuartal, semester, dan tahun dapat dianalisis menggunakan metode runtun waktu. Data runtun waktu dapat dijadikan dasar dalam pengambilan ketentuan untuk meramalkan kejadian yang terjadi di era yang akan datang.

Metode Autoregressive Integrated Moving Average (ARIMA) adalah model yang sangat populer dan sering digunakan dalam pemodelan data runtun waktu. Model ARIMA merupakan model peramalan yang menghasilkan ramalan-ramalan berdasarkan sintesis dari pola data secara historis. Dalam membuat peramalan model ARIMA tidak menggunakan variabel independen tetapi menggunakan nilai-nilai sekarang dan nilai-nilai lampau dari variabel dependen untuk menghasilkan peramalan jangka pendek yang akurat. Metode ARIMA sering digunakan untuk peramalan di berbagai bidang, salah satunya bidang transportasi.

Transportasi umum yang banyak digunakan oleh masyarakat Indonesia salah satunya adalah kereta api. Masyarakat memilih kereta api karena masyarakat membutuhkan transportasi massal dengan waktu tempuh relatif lebih cepat, terhindar dari kemacetan, nyaman, harganya ekonomis, tingkat keselamatan yang cukup tinggi, dan salah satu angkutan jarak jauh yang lebih efektif. Selain itu, kereta api menjadi transportasi alternatif terutama di daerah perkotaan yang sangat padat dengan angkutan perkotaan. Dalam realitanya, tidak jarang permintaan akan angkutan penumpang kereta api jauh lebih besar dibandingkan dengan kapasitas seat yang disediakan, sehingga sering menimbulkan penumpukan penumpang di berbagai stasiun (Sari dkk, 2016: 131). Permasalahan tersebut sering dihadapi seluruh daerah operasi PT. Kereta Api Indonesia khususnya di pulau Sumatera. Oleh karena itu, salah satu cara untuk mengatasinya dilakukan peramalan jumlah penumpang kereta api yang akan datang menggunakan model ARIMA.

Berikut ini beberapa penelitian menggunakan metode Box-Jenkins untuk pemodelan data runtun waktu. Indayani (2009), melakukan peramalan jumlah penumpang kereta api menggunakan metode Box-Jenkins. Ruhiat dan Effendi (2018), melakukan penelitian mengenai pengaruh faktor musiman pada pemodelan deret waktu untuk peramalan debit sungai dengan metode SARIMA. Efendi (2017), dalam skripsinya melakukan analisis peramalan jumlah penumpang kereta api menggunakan metode SARIMA. Tando, Komalig dan Nainggolan (2016), melakukan prediksi jumlah penumpang kapal laut di pelabuhan laut Manado menggunakan model ARMA. Desvina dan Syahfitra (2016), melakukan prediksi pertumbuhan perdagangan luar negeri provinsi Riau menggunakan metode Box-Jenkins.

Dari paparan di atas peneliti termotivasi untuk melakukan studi literatur tentang analisis data runtun waktu menggunakan model ARIMA. Penerapannya dalam bidang transportasi, khususnya jumlah penumpang PT. Kereta Api Indonesia di pulau Sumatera. Tujuan dari penelitian ini yaitu menentukan model ARIMA terbaik yang mampu menirukan dan meramalkan perilaku data historis, meramalkan jumlah penumpang kereta api menggunakan model ARIMA terbaik dan mengetahui tingkat kebaikan model ARIMA terbaik yang diperoleh.

Dikirim: 26 Juni 2018; Diterima: 17 September 2018; Dipublikasikan: 29 September 2018

Cara sitasi: Nurjanah, I.S., Ruhiat, D., dan Andiani, D. 2018. Implementasi Model Autoregressive Integrated Moving Average (ARIMA) untuk Peramalan Jumlah Penumpang Kereta Api di Pulau Sumatera. Jurnal Teorema: Teori dan Riset Matematika. Vol 3 No 2, Hal 145-156, September 2018. 


\section{METODE PENELITIAN}

Pemodelan untuk peramalan jumlah penumpang PT. Kereta Api Indonesia di pulau Sumatera menggunakan pendekatan metode Box-Jenkins, yaitu model ARIMA.

Metode ARIMA dengan derajat AR $(p)$, derajat selisih $d$ dan derajat MA $(q)$, maka modelnya ditulis ARIMA $(p, d, q)$ yang mempunyai bentuk umum sebagai berikut (William W. S. Wei, 2006):

$$
\begin{aligned}
Y_{t}= & \mu+\left(\beta_{1}+1\right) Y_{t-1}+\left(\beta_{2}-\beta_{1}\right) Y_{t-2}+\cdots+\left(\beta_{p}-\beta_{p-1}\right) Y_{t-p}-\beta_{p} Y_{t-p}+\varepsilon_{t}- \\
& \alpha_{1} \varepsilon_{t-1}-\cdots-\alpha_{q} \varepsilon_{t-q}
\end{aligned}
$$

dengan:

$Y_{t} \quad:$ data pada periode $t, t=1,2,3, \ldots, n$

$\mu \quad:$ konstanta model

$\alpha_{1} \ldots, \alpha_{q}:$ koefisien parameter moving average

$\beta_{1}, \ldots, \beta_{p}:$ koefisien parameter autoregressive

$Y_{t-p} \quad:$ data pada waktu $t-p, p=1,2,3, \ldots, p$

$\varepsilon_{t} \quad:$ nilai kesalahan pada waktu ke $-\mathrm{t}$

$\varepsilon_{t-q} \quad: \quad$ nilai kesalahan pada saat $t-q, q=1,2,3, \ldots, q$

Pemodelan dan peramalan melalui metode ARIMA terdiri atas beberapa tahapan, antara lain: identifikasi model, penaksiran parameter, uji diagnostik dan uji kebaikan model.

\section{Identifikasi Model}

Identifikasi model dilakukan dengan langkah-langkah sebagai berikut:

a. Membuat plot data untuk pengecekan pola musiman atau tidak.

b. Stasioneritas data, untuk melihat data stasioner dalam variansi atau dalam mean. Jika tidak stasioner dalam rata-rata maka dilakukan differencing, sedangkan jika tidak stasioner dalam variansi maka dilakukan transformasi.

c. Plot ACF dan PACF untuk melihat apakah data telah stasioner setelah dilakukan transformasi dan differencing, selain itu melihat plot ACF dan PACF juga dapat menduga model yang memungkinkan.

\section{Penaksiran Parameter}

Tahap selanjutnya yaitu mencari nilai penaksiran dari model yang memungkinkan kemudian dilanjutkan dengan uji signifikansi parameter model. Pengujian tersebut dilakukan untuk pemeriksaan bahwa model tersebut signifikan, yang berarti model layak digunakan. Proses penaksiran dan uji signifikansi parameter dapat dilakukan menggunakan software SPSS17.

\section{Uji Diagnostik atau Tahap Verifikasi}

Uji diagnostik White noise dan distribusi normal dilakuan melalui uji-uji berikut:

\section{a. Autokorelasi pada Nilai Sisa}

Untuk mengetahui apakah autokorelasi dari nilai sisa berbeda dengan nol atau tidak atau bersifat White noise dilakukan melalui uji Ljung-Box dengan hipotesis statistik:

$H_{0}: \rho_{1}=\rho_{2}=\cdots=\rho_{m}=0$ (Residual bersifat white noise)

$H_{1}: \rho_{k} \neq 0, k=1,2,3 \ldots, m \quad$ (Residual tidak bersifat white noise)

dan persamaan statistik uji Ljung-Box sebagai berikut:

$$
Q=n(n+2) \sum_{k=1}^{i}(n-k)^{-1} \hat{\rho}_{k}^{2}
$$


dimana:

$$
\begin{aligned}
& Q \quad \text { : statistika uji Ljung-Box } \\
& \rho \text { : merupakan autokorelasi } \\
& k \text { : lag waktu } \\
& i \text { : menyatakan banyaknya sisaan } \\
& n \text { : banyaknya parameter yang diduga }
\end{aligned}
$$

Kriteria keputusan yaitu apabila $p$-value $>\alpha$ maka terima $\mathrm{H}_{0}$ dan apabila $p$-value $<\alpha$ maka tolak $\mathrm{H}_{0}$

\section{b. Asumsi Residual Berdistribusi Normal}

Untuk mengetahui residual berdistribusi normal dilakukan dengan uji normalitas residual. Uji nomalitas residual dilakukan dengan uji Kolmogorov-Smirnov dengan hipotesis statistik:

$\mathrm{H}_{0}$ : Residual berdistribusi normal.

$\mathrm{H}_{1}$ : Residual tidak berdistribusi normal.

dan persamaan statistik uji Kolmogorov-Smirnov adalah sebagai berikut:

dimana:

$$
\text { Nilai }\left|F_{T}-F_{S}\right| \text { terbesar }
$$

$F_{T}$ : probabilitas komulatif normal

$F_{S}$ : probabilitas komulatif empiris

Kriteria keputusan:

(a) Jika nilai $\left|\mathrm{F}_{\mathrm{T}}-\mathrm{F}_{\mathrm{S}}\right|$ terbesar < nilai tabel kolmogorov smirnov atau $p-$ value $>\alpha$, maka Ho diterima, Ha ditolak.

(b) Jika nilai $\left|\mathrm{F}_{\mathrm{T}}-\mathrm{F}_{\mathrm{S}}\right|$ terbesar $>$ nilai tabel kolmogorov smirnov atau $p-$ value $<\alpha$, maka Ho ditolak, Ha diterima.

\section{Uji Kebaikan Model}

Penentuan model terbaik dilakukan melalui uji kebaikan model yang diperoleh dari nilai sisa. Terdapat beberapa metode yang dapat digunakan untuk uji kebaikan model berdasarkan nilai sisa, salah satunya adalah Mean Absolute Percentage Error (MAPE). Untuk menghitung MAPE digunakan rumus sebagai berikut:

dengan:

$$
M A P E=\frac{\sum_{t=1}^{n}|P E|}{n}
$$

$P E$ : nilai percentage error

$n$ : banyaknya pengamatan 


\section{HASIL DAN PEMBAHASAN}

\section{Identifikasi Model}

a. Plot Data Sumatera.

Berikut ini merupakan plot data jumlah penumpang PT. Kereta Api Indonesia di Pulau

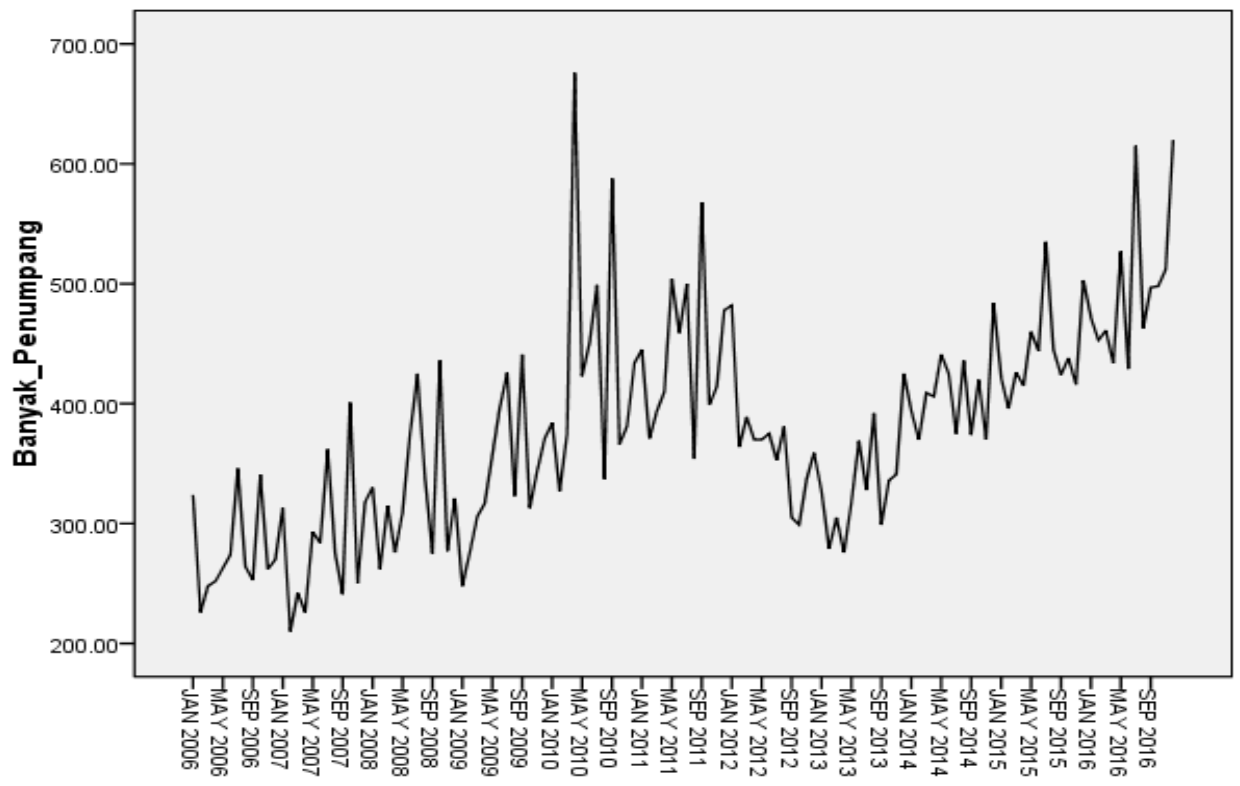

Sumber: Hasil Analisis Data

\section{Date}

\section{Gambar 1. Plot Data Runtun Waktu}

Plot data Gambar 1 memperlihatkan bahwa data belum stasioner terhadap variansi dan mean, karena seiring perjalanan waktunya data menunjukkan adanya trend, maka harus di stasionerkan.

\section{b. Stasioneritas Data}

1) Transformasi

Plot data runtun waktu setelah distasionerkan melalui transformasi natural log disajikan pada Gambar 2.

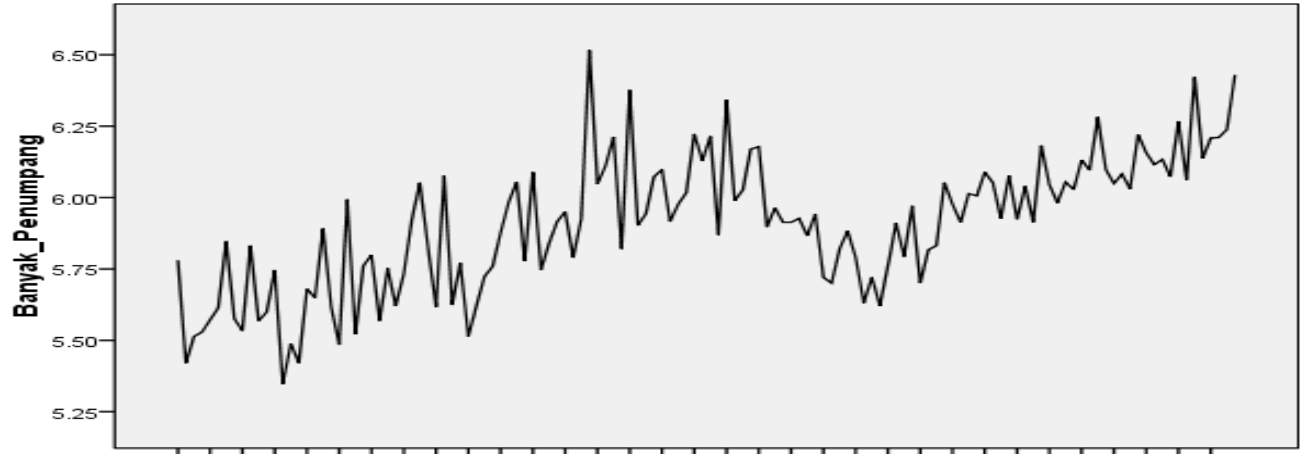

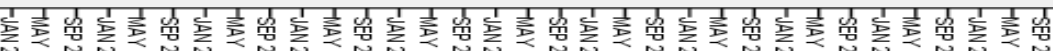

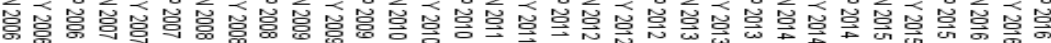

\section{Date}

Sumber: Hasil Analisis Data

\section{Gambar 2. Plot Data Hasil Transformasi}

Dikirim: 26 Juni 2018; Diterima: 17 September 2018; Dipublikasikan: 29 September 2018

Cara sitasi: Nurjanah, I.S., Ruhiat, D., dan Andiani, D. 2018. Implementasi Model Autoregressive Integrated Moving Average (ARIMA) untuk Peramalan Jumlah Penumpang Kereta Api di Pulau Sumatera. Jurnal Teorema: Teori dan Riset Matematika. Vol 3 No 2, Hal 145-156, September 2018. 
Dari plot Gambar 2 terlihat bahwa data masih belum stasioner dalam variansi maupun mean. Hal ini bisa dilihat masih ada unsur trend dalam data sehingga perlu dilakukan transformasi lanjutan melalui differencing.

\section{2) Differencing}

Berikut merupakan plot data runtun waktu penumpang kereta api yang sudah ditransformasi dan differencing.

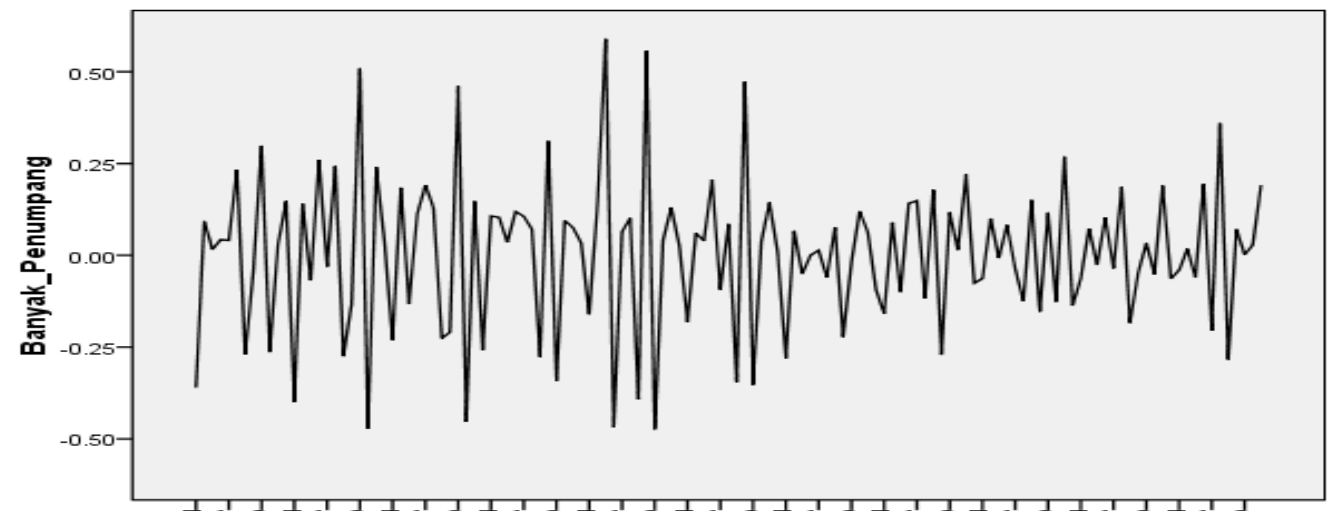

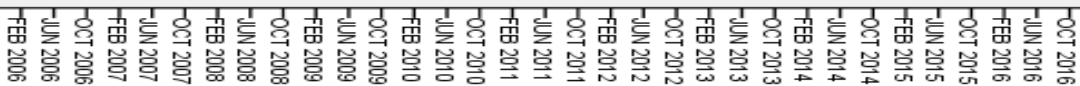

\section{Date}

Sumber: Hasil Analisis Data

\section{Gambar 3. Plot Data Hasil Transformasi dan Differencing}

Pada plot data hasil transformasi dan differencing, diperoleh bahwa data sudah stasioner dan sudah tidak ada unsur trend. Untuk lebih memastikan apakah data sudah stasioner dalam variansi dan mean yaitu dengan melihat plot ACF dan PACF.

\section{c. Plot ACF dan PACF}

Plot ACF (Autocorrelation Function) dan PACF (Partial Autocorrelation Function) akan disajikan pada Gambar 4 dan Gambar 5.

Banyak_Penumpang

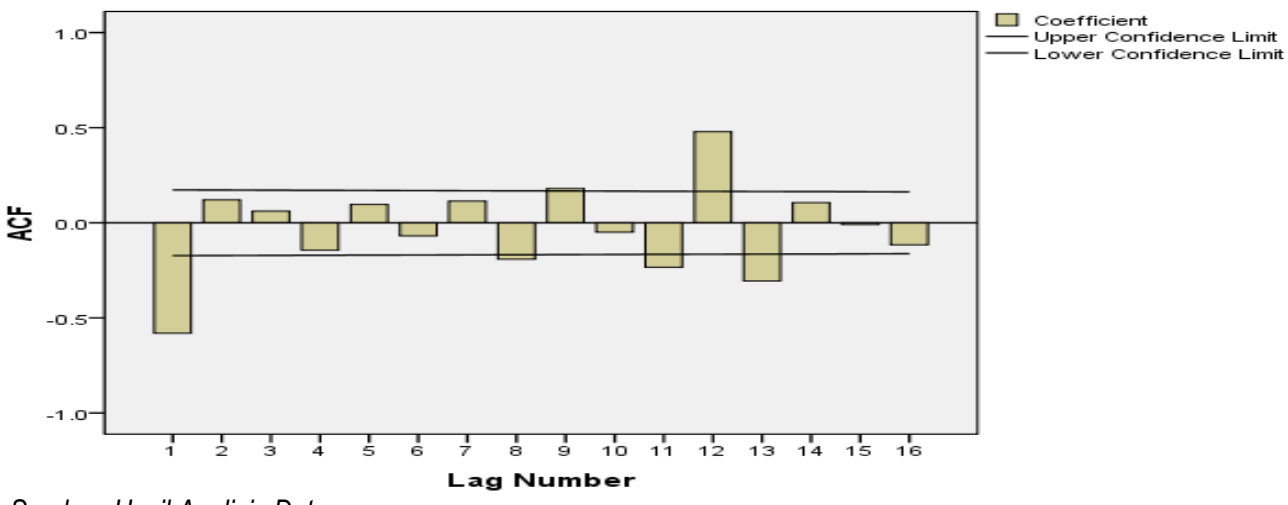

Sumber: Hasil Analisis Data

Gambar 4. Plot ACF Hasil Transformasi dan Differencing

Dikirim: 26 Juni 2018; Diterima: 17 September 2018; Dipublikasikan: 29 September 2018

Cara sitasi: Nurjanah, I.S., Ruhiat, D., dan Andiani, D. 2018. Implementasi Model Autoregressive Integrated Moving Average (ARIMA) untuk Peramalan Jumlah Penumpang Kereta Api di Pulau Sumatera. Jurnal Teorema: Teori dan Riset Matematika. Vol 3 No 2, Hal 145-156, September 2018. 


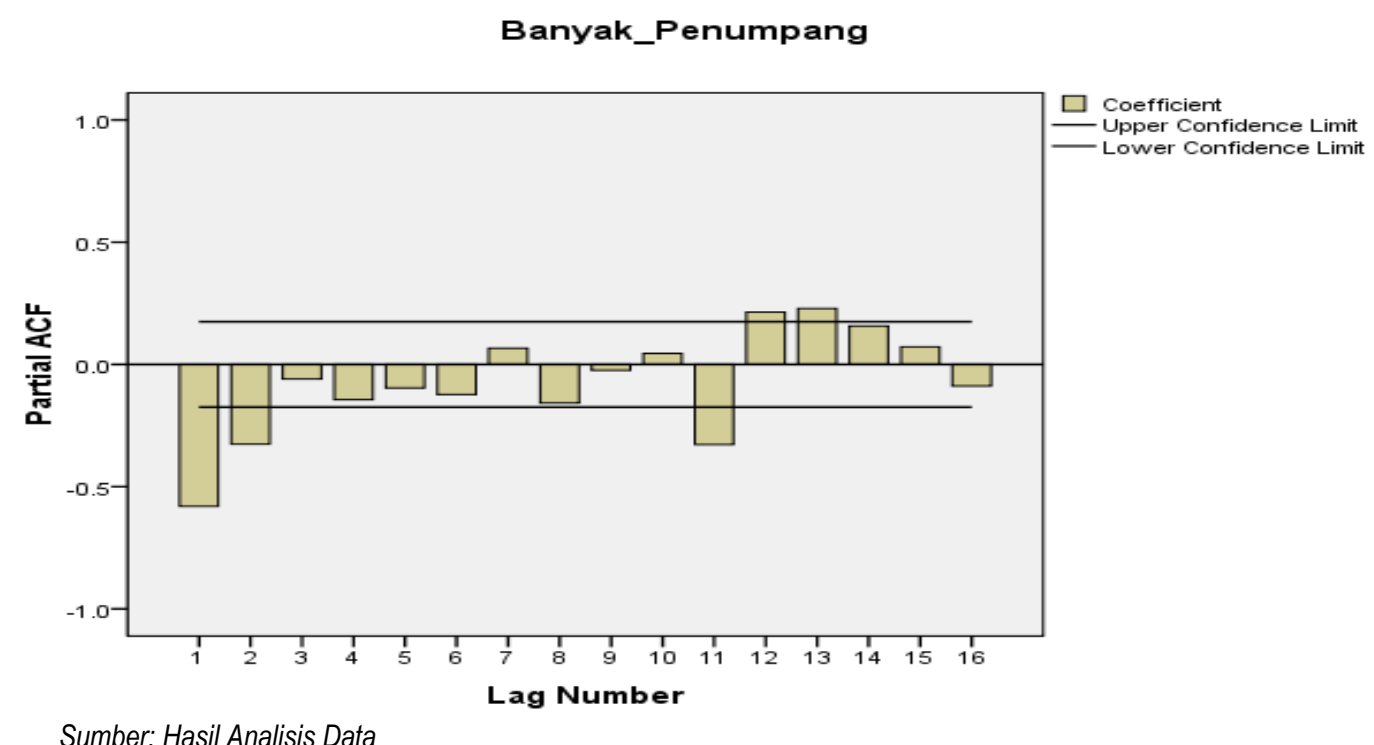

Gambar 5. Plot PACF Hasil Transformasi dan Differencing

Dari plot ACF dan PACF hasil seluruh data ditransformasi dan differencing terlihat bahwa data sudah stasioner dalam variansi dan dalam mean, karena pada lag-lag awal telah cut off. Setelah diperoleh data stasioner dalam variansi dan mean langkah selanjutnya yaitu menduga model yang cocok untuk digunakan. Dari analisa data di atas model ARIMA yang akan digunakan yaitu model ARIMA $(2,1,1)$. Walaupun tidak menutup kemungkinan terdapat model ARIMA lain yang terbentuk. Model-model ARIMA yang diduga cocok untuk data runtun waktu dari jumlah penumpang PT. Kereta Api Indonesia di Pulau Sumatera adalah sebagai berikut:

a. $\operatorname{ARIMA}(2,1,1)$

b. $\operatorname{ARIMA}(2,1,0)$

c. $\operatorname{ARIMA}(1,1,1)$

d. $\operatorname{ARIMA}(1,1,0)$

e. $\operatorname{ARIMA}(0,1,1)$

Setelah diperoleh model-model ARIMA yang mungkin, langkah selanjutnya adalah mengestimasikan parameternya.

\section{Estimasi Parameter Model dan Uji Signifikan}

Setelah memperoleh model sementara, langkah selanjutnya adalah estimasi parameter model sementara dengan bantuan software SPSS 17. Berikut merupakan output estimasi parameter dari software SPSS 17:

Tabel 1. Perbandingan ARIMA Nilai Berdasarkan Model

\begin{tabular}{|c|c|c|c|c|c|}
\hline & ARIMA & ARIMA & ARIMA & ARIMA & ARIMA \\
& $(2,1,1)$ & $(2,1,0)$ & $(1,1,1)$ & $(1,1,0)$ & $(0,1,1)$ \\
\hline$c$ & 0.005 & 0.006 & 0.005 & 0.005 & 0.05 \\
Sig. & $(0.134)$ & $(0.390)$ & $(0.149)$ & $(0.555)$ & $(0.102)$ \\
\hline AR (1) & -0.173 & -0.804 & -0.222 & -0.594 & \\
Sig. & $(0.257)$ & $(0.000)$ & $(0.050)$ & $(0.000)$ & - \\
\hline AR (2) & 0.055 & -0.352 & & & - \\
Sig. & $(0.675)$ & $(0.000)$ & - & - & 0.773 \\
\hline MA (1) & 0.714 & & 0.670 & & $(0.000)$ \\
Sig. & $(0.000)$ & - & $(0.000)$ & - & \\
\hline
\end{tabular}

Sumber: Hasil Pengolahan Data

Dikirim: 26 Juni 2018; Diterima: 17 September 2018; Dipublikasikan: 29 September 2018

Cara sitasi: Nurjanah, I.S., Ruhiat, D., dan Andiani, D. 2018. Implementasi Model Autoregressive Integrated Moving Average (ARIMA) untuk Peramalan Jumlah Penumpang Kereta Api di Pulau Sumatera. Jurnal Teorema: Teori dan Riset Matematika. Vol 3 No 2, Hal 145-156, September 2018. 


\section{Tahap Verifikasi}

Langkah selanjutnya akan dilakukan tahap verifikasi dengan grafik ACF residual dan PACF residual dan uji kenormalan residual. Resume hasil pengujian disajikan pada tabel berikut.

Tabel 2. Perbandingan Model Berdasarkan Asumsi

\begin{tabular}{|l|l|l|l|l|l|}
\hline & ARIMA & ARIMA & ARIMA & $\begin{array}{l}\text { ARIMA } \\
(1,1,0)\end{array}$ & $\begin{array}{l}\text { ARIMA } \\
(0,1,1)\end{array}$ \\
\hline White Noise & Terpenuhi & Terpenuhi & Terpenuhi & $\begin{array}{l}\text { Tidak } \\
\text { terpenuhi }\end{array}$ & Terpenuhi \\
& & & Terpen & Terpenuhi \\
\hline Normalitas & Terpenuhi & Terpenuhi & Terpenuhi & Terpenuhi & Tumber: Hasil Pengolahan Data \\
Sumben
\end{tabular}

\section{Uji Kebaikan Model}

Pengujian kebaikan model dilakukan terhadap semua kemungkinan model yang ada. Resume nilai Mean Absolute Percentage Error (MAPE) untuk beberapa model disajikan pada tabel berikut.

Tabel 3. Hasil Nilai MAPE

\begin{tabular}{|l|l|l|l|l|l|}
\hline & ARIMA & ARIMA & ARIMA & ARIMA & ARIMA \\
& $(2,1,1)$ & $(2,1,0)$ & $(1,1,1)$ & $(1,1,0)$ & $(0,1,1)$ \\
\hline MAPE & 12.283 & 12.657 & 12.277 & 13.583 & 12.343 \\
\hline
\end{tabular}

Dari Tabel 3 terlihat bahwa nilai MAPE dari semua model yaitu antara 10\% sampai $20 \%$ yang berarti semua model cukup bagus.

\section{Pemilihan Model Terbaik}

Langkah selanjutnya melakukan pemilihan model terbaik dari semua kemungkinan model dengan cara melihat ukuran-ukuran standar ketepatan peramalan.

Berdasarkan dari semua tabel di atas, model yang terpilih adalah model ARIMA $(1,1,1)$ karena signifikansi pada koefisien AR (1) dan MA (1) tanpa melihat koefisien konstan, terpenuhi dari semua asumsi dan mempunyai nilai MAPE in sample yang paling kecil yaitu sebesar 12.277 atau $12.28 \%$. Dengan demikian terlihat bahwa model ARIMA $(1,1,1)$ merupakan model terbaik untuk data jumlah penumpang PT. Kereta Api Indonesia di Pulau Sumatera.

\section{Peramalan}

Setelah memperoleh model terbaik langkah selanjutnya adalah menentukan peramalan untuk periode ke depan. Dalam pembahasan ini akan diramalkan jumlah penumpang untuk 12 periode ke depan. Hasil peramalannya disajikan pada Tabel 4 yaitu: 
Tabel 4. Hasil Peramalan

\begin{tabular}{|c|c|}
\hline Bulan & Hasil Peramalan \\
\hline Jan-2017 & 529 \\
\hline Feb-2017 & 553 \\
\hline Mar-2017 & 552 \\
\hline Apr-2017 & 556 \\
\hline Mai-2017 & 559 \\
\hline Jun-2017 & 563 \\
\hline Jul-2017 & 567 \\
\hline Aug-2017 & 570 \\
\hline Sep-2017 & 574 \\
\hline Okt-2017 & 577 \\
\hline Nov-2017 & 581 \\
\hline Des-2017 & 585 \\
\hline
\end{tabular}

Sumber: Hasil Pengolahan Data

Dari Tabel 4 dapat disimpulkan bahwa hasil analisis menggunakan model ARIMA $(1,1,1)$ mengalami kenaikan setiap bulannya kecuali bulan Maret. Berikut ini plot data setelah dilakukan peramalan 12 periode kedepan.

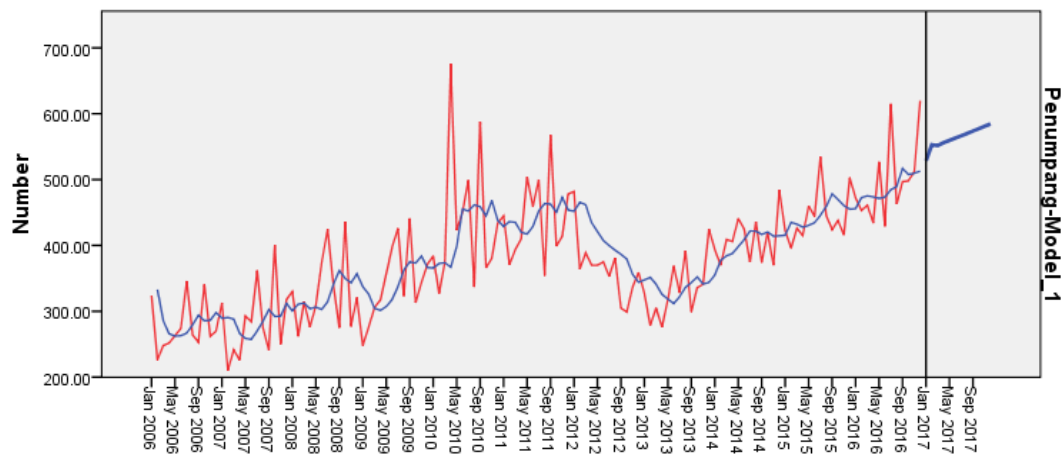

Sumber: Hasil Analisis Data

Date

\section{Gambar 6. Plot Hasil Peramalan}

Perhitungan peramalan jumlah penumpang kereta api untuk periode selanjutnya dengan menggunakan model ARIMA $(1,1,1)$ dapat dituliskan sebagai berikut:

$$
Y_{t}=0.005+0.778 Y_{t-1}+0.222 Y_{t-2}+\varepsilon_{t}-0.670 \varepsilon_{t-1}
$$

\section{Kalibrasi Model}

Langkah terakhir dalam analisis runtun waktu adalah melakukan kalibrasi. Kalibrasi pada penelitian ini akan menggunakan data perbandingan hasil peramalan dan data aktual selama 10 bulan. Data perbandingan hasil ramalan dan data asli untuk periode kedepan dapat disajikan dalam Tabel 5. 
Tabel 5. Perbandingan Hasil Ramalan dan Data Asli untuk 8 Periode Kedepan

\begin{tabular}{|c|c|c|c|c|}
\hline Bulan & $\begin{array}{c}\text { Periode } \\
n\end{array}$ & $\begin{array}{c}\text { Aktual } 2017 \\
X_{t}\end{array}$ & $\begin{array}{c}\text { Forecast } 2017 \\
F_{t}\end{array}$ & $\left|\frac{X_{t}-F_{t}}{X_{t}}\right|$ \\
\hline Januari & 133 & 590 & 529 & 0.103 \\
\hline Febuari & 134 & 505 & 553 & 0.095 \\
\hline Maret & 135 & 558 & 552 & 0.011 \\
\hline April & 136 & 568 & 556 & 0.021 \\
\hline Mei & 137 & 588 & 559 & 0.049 \\
\hline Juni & 138 & 542 & 563 & 0.039 \\
\hline Juli & 139 & 641 & 567 & 0.115 \\
\hline Agustus & 140 & 536 & 570 & 0.063 \\
\hline September & 141 & 577 & 574 & 0.005 \\
\hline Oktober & 142 & 572 & 577 & 0.009 \\
\hline \multicolumn{4}{|c|}{ Jumlah } & 0.511 \\
\hline \multicolumn{4}{|c|}{ MAPE } & 5.112 \\
\hline
\end{tabular}

Dari Tabel 5 diperoleh nilai MAPE out of sample $5.11 \%$ itu artinya tingkat keakuratan model sebesar $94.89 \%$, maka dapat dikatakan peramalan dengan model ARIMA $(1,1,1)$ cukup baik. Untuk lebih jelasnya dapat dilihat pada Gambar 7.

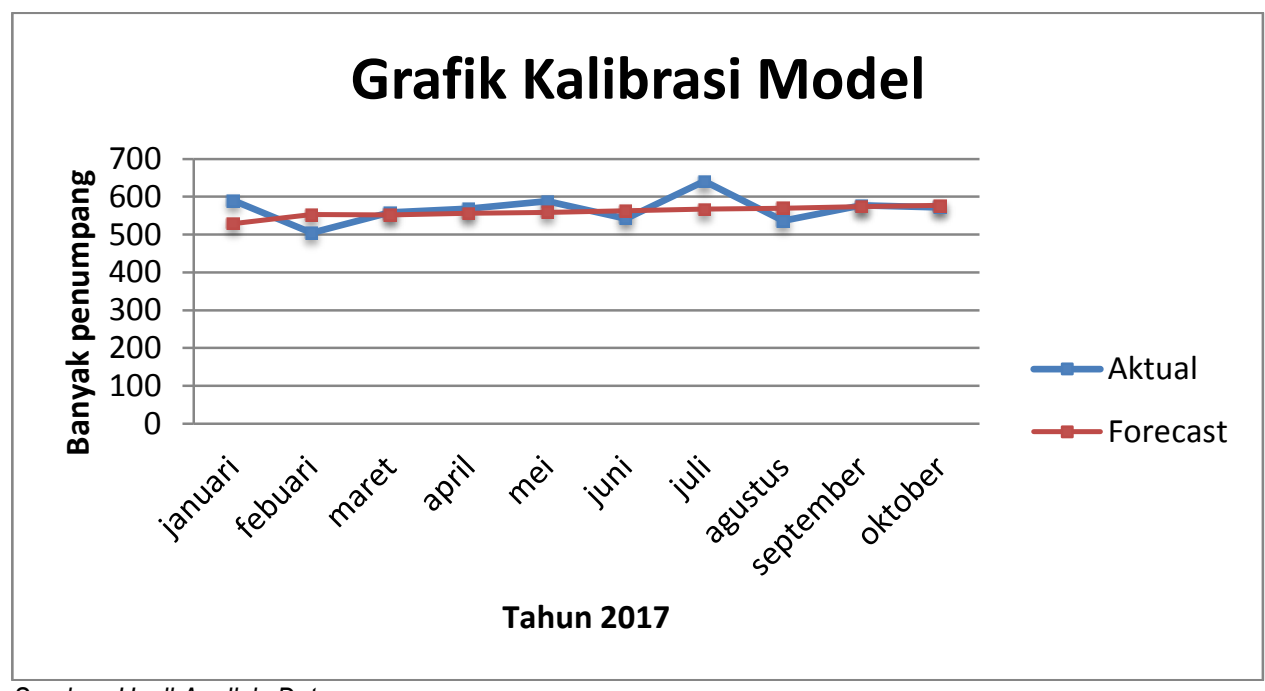

Sumber: Hasil Analisis Data

\section{Gambar 7. Plot Hasil Peramalan dan Data Aktual untuk Jumlah Penumpang Kereta Api Tahun 2017}

Dari grafik Gambar 7 terlihat saling berpotongan di beberapa titik dengan selisih yang tidak terlalu besar. Hal ini menunjukkan bahwa dari hasil peramalan menggunakan model ARIMA $(1,1,1)$ dapat melakukan peramalan dengan hasil yang memuaskan. 


\section{KESIMPULAN}

Beberapa kesimpulan yang diperoleh dari hasil penelitian ini adalah sebagai berikut:

1. Model ARIMA terbaik yang mampu menirukan dan meramalkan perilaku data historis berdasarkan uji signifikansi tanpa melihat koefisien konstan, tahap verifikasi dan uji kebaikan model yang telah terpenuhi adalah model ARIMA $(1,1,1)$. Dengan menggunakan bantuan software SPSS 17 diperoleh hasil analisis nilai parameter sebagai berikut:

$$
\mu=0.005 ; \beta_{1}=-0.222 ; \alpha_{1}=0.670
$$

maka diperoleh persamaan sebagai berikut:

$$
Y_{t}=0.005+0.778 Y_{t-1}+0.222 Y_{t-2}+\varepsilon_{t}-0.670 \varepsilon_{t-1}
$$

2. Model ARIMA $(1,1,1)$ memiliki nilai MAPE in sample $12.28 \%$ dan nilai MAPE out of sample (kalibrasi) $5.11 \%$. Dengan demikian nilai MAPE out of sample lebih kecil dari MAPE in sample. Hal ini menunjukkan bahwa metode ARIMA $(1,1,1)$ layak digunakan untuk prediksi data runtun waktu dari jumlah penumpang PT. Kereta Api Indonesia di Pulau Sumatera.

3. Hasil peramalan jumlah penumpang PT. Kereta Api Indonesia di Pulau Sumatera untuk 12 periode ke depan menggunakan metode ARIMA $(1,1,1)$ yaitu bulan Januari 2017 sebanyak 529 penumpang, bulan Februari 2017 mengalami kenaikan sehingga banyaknya penumpang adalah 553, bulan Maret 2017 mengalami penurunan sehingga banyaknya penumpang menjadi 552, bulan April 2017 sampai dengan bulan Desember 2017 diprediksi jumlah penumpang akan naik terus hingga mencapai 585 penumpang.

\section{REKOMENDASI}

Berdasarkan penelitian dan pembahasan dalam studi literatur tentang data runtun waktu menggunakan metode ARIMA, penulis dapat memberikan beberapa saran yang sekiranya layak untuk disampaikan dari hasil penelitian sebagai berikut:

1. Pemodelan data runtun waktu terhadap data yang sama, yaitu data jumlah penumpang PT KAI di Pulau Sumatera, dapat dicoba dengan menggunakan beberapa model lainnya antara lain SARIMA, ARIMAX, ESTAR, ARCH, GARCH dan SSA.

2. Proses pengolahan dan analisis data dalam penelitian ini selain dapat digunakan bantuan software SPSS 17, juga dapat dilakukan dengan menggunakan bantuan beberapa software lainnya, yaitu Minitab, Eviews, SAS dan R.

\section{UCAPAN TERIMAKASIH}

Penulis mengucapkan terima kasih kepada Dadang Ruhiat, S.Si, MPSDA, M.Stat dan Dini Andiani, S.Si, M.Pd yang telah mendukung dan membimbing dalam penyelesaian penelitian ini hingga bisa tersusun dalam paper untuk dipublikasikan.

\section{DAFTAR PUSTAKA}

Desvina, A.P. dan Syahfitra, M. 2016. Aplikasi Metode Box-Jenkins dalam Memprediksi Pertumbuhan Perdagangan Luar Negeri Provinsi Riau. Jurnal Sains Matematika dan Statistika. Vol 2 No 2, Hal 12-20, Juli 2016.

Efendi, S.R. 2017. Analisis Peramalan Jumlah Penumpang Kereta Api dengan Metode SARIMA. Skripsi. Yogyakarta: Universitas Islam Negeri Sunan Kalijaga. 
Indayani, E.F. 2009. Peramalan Jumlah Penumpang Kereta Api dengan Menggunakan Metode BoxJenkins (Studi Kasus di PT. Kereta Api (persero) DAOP VI Yogyakarta). Skripsi. Yogyakarta: Universitas Islam Negeri Sunan Kalijaga.

Makridakis, S., Wheelwright, S.C.dan McGee, V.E. 1983. Metode dan Aplikasi Peramalan Jilid 1. Terjemahan oleh Untung Sus Andriyanto dan Abdul Basith 1999. Edisi Kedua. Jakarta: Erlangga.

Ruhiat, D. dan Effendi, A. 2018. Pengaruh Faktor Musiman pada Pemodelan Deret Waktu untuk Peramalan Debit Sungai dengan Metode SARIMA. Jurnal Teorema: Teori dan Riset Matematika. Vol 2 No 2, Hal 117-128, Maret 2018.

Sari, D.P., Darmawan, G. dan Soemartini. 2016. Peramalan Jumlah Penumpang Kereta Api Lodaya Jurusan Bandung-Solo Menggunakan Model Reg-ARIMA dengan Variasi Kalender (Studi Kasus: PT. kereta api Indonesia). Prosiding Seminar Nasional MIPA 2016. Peran Penelitian IImu Dasar dalam Menunjang Pembangunan Berkelanjutan: 131-135. Jatinangor, 27-28 Oktober 2016: Departemen Statistika, FMIPA Universitas Padjajaran.

Tando, J., Komalig, H., dan Nainggolan, N. 2016. Prediksi Jumlah Penumpang Kapal Laut di Pelabuhan Laut Manado Menggunakan Model Arma. Jurnal de Cartesian. Vol 5 No 2, Hal 95-99, September 2016.

Wei, W.W.S. 2006. Time Series Analysis Univariate and Multivariate Methods, Second Edition. New York: Pearson Education. https://www.bps.go.id/LinkTableDinamis/view/id/815. Diakses Tanggal 30 Desember 2017. 